負担が軽減されるようになった)，今回の改正は，第 1 に，未成年養子制度のなか でも, 特に特別養子制度は, 要保護性のある他児養子を促す養子制度として位置づ けられていること, 第 2 に, 他児養子によって形成される非血縁の親子関係が, 政 策的かつ積極的に創設されようとしていることを示す.したがって, 非血縁親子を 特別養子制度の観点から分析した本書は, 今後の養子制度研究における貴重な視座 を与えるものといえよう。

\title{
[文献]
}

有賀喜左衛門, 1970, 『有賀喜左衛門著作集 9 家と親分子分』未来社.

中川善之助, 1952, 『日本の家族制度』培風館.

新明正道, 1937, 「血緣論」穂積重遠 - 中川善之助責任編集『家族制度全集 史論篇 3 親子』河出書 房, 1-17.

山畠正男, 1994, 「日本の養子制度」中川善之助 - 山畠正男編『新版 注釈民法 (24) 親族 (4)』有斐 閣, 91-107.

\section{竹田恵子 著}

\section{『不妊，当事者の経験一日本におけるその変化 20 年』}

（洛北出版，2018 年，四六判，589 頁，2,700 円+税）

柘植あづみ

日本は体外受精・胚移植の 1 年間の実施件数が世界第 1 位であるが，第三者が関 わる提供卵子による体外受精の件数は少なく, 代理出産はごくわずかしか実施され ていない, それでも, 経済格差を利用し, 規制の枠をも越える海外へ渡航して第三 者が関わる生殖技術（生殖補助技術：ARTとも呼ぶ）によって子どもを得ようと する人は少なくない。 その一方, 日本では, 受精卵のゲノム編集, iPS 細胞からの 精子や卵子の作製, 子宮移植などが「不妊治療」への応用を目的として研究されて いる．不妊治療をしていて，なかなか期待する結果が得られない人たちは，このよ うな新たな技術を提示されて「躊躇」する.

本書は, 2000 年代初期と 2010 年代初期に不妊治療をした人々へのインタビュー 調査とアンケート調査から不妊治療の当事者の「躊躇」とその変容に焦点を当てて 考察した 580 頁を超える労作である.

不妊治療の何に戸惑い, なぜ躊躇するのか, 日本の不妊治療の現実を当事者がい かに受け止め行動したのかなどを, それぞれの年代による違いを比較しながら丁寧 に描きだしている，たとえば, 2000 年代初期の調査では, いつ結果が出るのかわ 
からず，治療に伴うリスクがある不妊治療を続けることへの躊躇に加えて，生命へ の介入やパートナーとの性交を介さずに妊娠することに対する「自然」な方法で子 どもをもうけるべきといった価值観と対立する倫理的な躊躇などが抽出される。 そ れと比べ, 2010 年代初期の不妊治療に関する躊躇では, 治療に伴うリスクなどへ の不安からくる躊躇は減じ, 倫理的な躊躇はあるものの, 2000 年代初期の調査よ りも短期間で消えたことが指摘されている.

気にかかったのは, 第 6 章に扔いて不妊治療の当事者がその経験から獲得した 「『素人』としてふるまう」ことを「躊躇を克服する知恵と技術」と名付けたことで ある.ここでの「素人」が医療社会学や医療人類学, 科学技術論等において専門家 と対をなす素人 (lay person) として用いられていることは了解した上で，また， 治療の経験と知識が豊富な人が,「『素人』としてふるまう」ことを描きだしたこと は高く評価するが，なぜそれを「躊躇を克服する知恵と技術」と呼ぶのかという疑 問である，不妊治療の当事者が，科学知識をあえて遠ざけ，医師にお任せすること を選び,「無知のままがいい」とすることによってなかなか成果が表れない不妊治 療を継続していくのは, 躊躇の克服ではなく, 専門家としての医師と「素人」の患 者の非対称性を固定化する行為ではないのか. むしろ, 不妊治療の当事者が医療・ 医学の知識をつけることがなぜ治療実践を難しくするのか, 躊躇する「素人」の経 験や知恵を医療の改善につなげる方法はないのかの考察を期待する. 評者は不妊治 療の当事者が「素人」の知恵と技術を身につけることを批判しているのでは決して なく, 患者があえて「素人」として振る舞わなければ成立しない治療がなぜ存在す るのかに疑問を抱いたことを補足しておきたい.

第 7 章と第 8 章では躊躇をめぐる文化社会的要因と社会的統制について論じられ る. 本書のクライマックスである. 不妊が医療化されて「不妊 (症)」と診断され た女性あるいは男性は患者役割を求められることは先行研究でも指摘されているが, 丁寧なインタビュー調查をもとにした著者の本領はここから発揮される. 不妊治療 に対する女性の感情が，たとえば，失敗によって妊娠できなかったことを悲しみ， 治療に注いだ時間と金銭を惜しむという単純なものではなく, 周囲からの助力に応 えられなかったこと, 職場に気を遣いながら不妊治療に通ったのに成果がでなかっ たこと，仕事が忙しくて治療に真剣に向き合わなかったという自責の念などからな ることを,「聞き手」と「話し手」との遣り取りから解きほぐしている，著者はそ れを「互いに相手の胸中を慮り，応えようとする〈感応〉の営み」と表現する。こ の〈感応〉の営みによって得られた調查結果が多く示されていることが, この本の 醍醐味である。

不妊治療の当事者が抱く躊躇に着目し, 躊躇の多面性, 多義性を解き明かしたの は秀逸である，ただ，冒頭に示したような新たな技術が応用されつつある場面で， 当事者は躊躇して拒否し続けるわけではない. 躊躇が消えて受容する場合もあれば, 躊躇したまま受容する場合もある，最初から躊躇しない場合もある．本書では躊躇 という感情がいかに生起するのか, それが時代とともにいかに変化するのかを検討 
したが，それでは，躊躇することが新たな技術導入の場面でいかなる意味をもつの かもたないのか, そして不妊治療を躊躇せずに受けられる社会が望ましいのかなど の疑問が浮かぶ.これからの調査に扔いてさらに考察が深められるのを期待したい.

前田泰樹・西村工ミ 著

\section{『遺伝学の知識と病いの語り——遺伝性疾患をこえて生きる』}

(ナカニシヤ出版, 2018 年, 四六判, 232 頁, 2,700円+税)

\section{土 屋 敦 \\ (関西大学社会学部准教授)}

ヒトゲノム計画が 1990 年に開始されてから 30 年, 配列の解読が終了してから, はや 17 年の月日が流れた。 そのプロセスの中で, 多くの疾患遺伝子が同定される とともに，近年では，がんや生活習慣病などの発症リスクや薬理応答性，その他さ まざまなヒトの疾患や特質が遺伝学的知識と関連付けられて理解されるようになっ てきている. その意味で，この 2 30 年余りの遺伝学的知識の蓄積は，医療者にと ってもクライアントにとっても, 病いの捉え方を大きく改変させてきた大きな出来 事であった。本書で取り上げられる多発性囊胞腎（PKD）も，そうしたプロセス の中で, 1990 年代半ばに原因遺伝子が同定され，また 2014 年に疾患の進行を抑制 する治療薬（トルバプタン）が認可された単一遺伝性疾患であり，同時期における 遺伝学的知識の膨大な蓄積の中で, その位置付けや分類のされ方が大きく変容して きた疾患の 1 つである。

本書は, こうした遺伝学的知識が「ある時代の社会にどのようなインパクトを与 え，それに対して，関係する人びとがいかにそれを理解しつつ対応してきたのか」 （まえがき 7 頁）を分析することを企図して, 概念分析の社会学と病いの語り論を 理論的支柱に据えながら展開される。序章では，遺伝学的知識が「だれにとって， どのような意味をもつものなのだろうか」（1 頁）を問いながら, リスクやメンバ ーシップ, カテゴリーとループ効果, 遺伝学的シチズンシップ, といった社会学上 の諸概念の整理がなされる，第 1 章では，当事者たちが「自らの身体の不調や痛み をどのように位置づけ, 医療者から伝えられた遺伝学的知識をどのように理解し, さまざまなこととどのように折り合いをつけてきたのか」（23 頁）が, 多発性囊胞 腎を生きる人々への聴き取り調査から明らかにされる. 多発性囊胞腎は 1990 年代 半ばに原因遺伝子の特定がなされるが，当事者がそうした「新しい知識」とどのよ うに出会い, いかなるかたちで自らの経験を構成したのかがそこでは問われる，第 2 章では, 多発性囊胞腎を生きる当事者たちが, 同じ「病い」を生きる患者会を経 由することで自らの病いの位置付けを変容させていく経緯が分析される. 第 3 章で 